\title{
Association of ITPA Gene Expression and Hematological Abnormalities Induced by Dual therapy in HCV-infected Patients
}

\author{
Naglaa ELarabany ${ }^{* 1}$, Nahed A. Omar ${ }^{1}$, Mostafa Mohammed Elshaer ${ }^{2}$, Ahmed Abdelkhalek ${ }^{3}$ and Mai Alaa Eldin \\ Ali Rashed ${ }^{1}$ \\ ${ }^{1}$ Department of Zoology, Faculty of Science, Damietta University, Damietta, Egypt. \\ ${ }^{2}$ Department of Microbiology at specialized medical Hospital, Mansoura University, Egypt. \\ ${ }^{3}$ Plant Protection and Bimolecular Diagnosis Department, ALCRI, City of Scientific. Research and Technological \\ Applications, New Borg El Arab city, Alexandria 21934, Egypt
}

Received: 4 April 2021 /Accepted: 10 April 2021

*Corresponding author's E-mail: Elarabany@gmail.com.

\begin{abstract}
The combination therapy has been the standard treatment for chronic hepatitis $\mathrm{C}$ virus (HCV) infection, but many patients have side effects due to this therapy. Recently, new direct-acting antivirals (DAAs) have enhanced the response rate, especially in difficult-to-treat patients infected with HCV genotypes (GT) 1 or 4, and have made adverse effects less common. RBV plays continually an important role in HCV therapy even with the introduction of DAAs. Hemolytic anemia is a common side effect in $\mathrm{HCV}$-infected patients on combination therapy, affecting up to $30 \%$ of patients, which needs to followup hemoglobin and dose modification in up to $15 \%$ of patients. RBV-induced anemia primarily results in the reduction of adenosine triphosphate (ATP) levels in erythrocytes, affecting ATP-dependent oxidative metabolism. Genetic variations in the inosine triphosphatase (ITPA) gene, which encodes an inosine triphosphate pyrophosphohydrolase (ITPase), protect from hemolytic anemia during dual therapy. These ITPA variants affect ITPase functionality, causing a drop in its activity, resulting in an accumulation of inosine triphosphate (ITP) in erythrocytes and the prevention of oxidative stress. The functional variants in ITPA gene leads to ITPase deficiency and a strong accumulation of ITP in erythrocytes, which is associated with lower RBV-toxicity. These genetic variants have been associated with protection from anemia.
\end{abstract}

Keywords: ITPA, Hemolytic anemia, Ribavirin, Chronic hepatitis C, HCV therapy.

\section{Introduction}

Hepatitis C virus (HCV) infection has a worldwide prevalence of approximately $2.2-$ $3.0 \%$ affecting approximately 130 to 170 million people worldwide (Lavanchy, 2009). The treatment success with ribavirin therapy, defined as sustained virological response (SVR), has been reported to be between 54\% and $63 \%$ in clinical trial settings (Manns et al., 2001; Fried, 2002 and McHutchison et al., 2007). Hematological abnormalities including 
neutropenia, anemia, and thrombocytopenia are commonly seen in patients with chronic hepatitis C treated with ribavirin therapy (Jagdish et al., 2010). Recent studies indicate that the combination therapy which contained ribavirin is effective for chronic hepatitis $\mathrm{C}$ virus (HCV) infection. However, reversible hemolytic anemia is a common side effect of this therapy (Shintaro et al., 2004). Hematological abnormalities were based on the dosage reduction guidelines in the package inserts for ribavirin. Anemia was defined as hemoglobin less than $10 \mathrm{gm} / \mathrm{dl}$, neutropenia was defined as an absolute neutrophil count less than 750 cells $/ \mathrm{mm}^{3}$, and thrombocytopenia was defined as a platelet count less than 50,000 cells $/ \mathrm{mm}^{3}$ (Jagdish et al., 2010). Adherence and optimal dosing positively influence SVR rates (McHutchison et al., 2002; Mulhall et al., 2005 and Reau et al., 2008). Adherence is decreased by side effects such as multiple hematological abnormalities including neutropenia, anemia, and thrombocytopenia. The side effects can be managed by reducing the doses of ribavirin but suboptimal doses negatively affect treatment outcomes. Timing of growth factors such as erythropoietin in the early stages of hematological abnormalities can ensure patient compliance while maintaining or improving patient quality of life (McHutchison et al., 2007 and Reau et al., 2008). But these growth factors take several weeks to attain full potential; hence, early detection of hematological abnormality becomes very important. If we can identify patients who are at risk of developing hematological abnormalities before start of therapy, these patients can be monitored more aggressively, and timely decisions for additional interventions such as growth factors can be made. Such interventions can improve patient outcomes. One of the most common hematological abnormalities associated with the use of ribavirin and chronic hepatitis $\mathrm{C}$ (CHC) infection is the development of dosedependent hemolytic anemia (McHutchison $\boldsymbol{e t}$ al., 2007). Other hematological abnormalities associated with the use of ribavirin are the development of neutropenia and thrombocytopenia. (Ong et al., 2004 and Kowdley, 2005). Inosine triphosphatase (ITPA) gene, located on chromosome 20, is involved in the protection against RBV-induced hemolytic anemia. Genetic polymorphisms in
ITPA gene were associated with two functional variants that resulted in ITPase deficiency with subsequent prevention of depletion of erythrocyte adenosine triphosphate (ATP), oxidative damage to the erythrocyte membrane (Hitomi et al., 2011) and eventual protection against RBV-induced hemolytic anemia (Fellay et al., 2010). The highest reduction in ITPA activity was due to mutation in exon 2 (94C $>$ A), where heterozygotes (CA) had $22.5 \%$ residual activity and homozygotes (AA) had zero activity (Sumi $\boldsymbol{e t}$ al., 2002). ITPA hydrolyzes inosine triphosphate (ITP) and deoxy inosine triphosphate. Deficiency or reduced function of the ITPA protein leads to accumulation of ITP. ITP can substitute for guanosine triphosphate (GTP) (which is depleted by RBV) as a substrate for adenylosuccinate synthase to produce adenylosuccinate, which can be further converted into ATP. It has been shown that RBV reduces erythrocyte ATP levels. Thus, in ITPA deficient patients, ITP accumulates in the erythrocytes and helps restore ATP levels, preventing lysis due to loss of ATP (Hitomi $\boldsymbol{e t}$ al., 2011). Inosine triphosphatase (ITPA) gene variants can protect against ribavirin (RBV)induced anemia in patients treated for chronic hepatitis $\mathrm{C}$. The genetic variation in Inosine Triphosphate Pyrophosphatase (ITPA) encoding inosine triphosphatase (ITPase) was a protective factor against hemolytic anemia in patients receiving RBV therapy (Fellay $\boldsymbol{e t}$ al., 2010 and Thompson et al., 2011). The ITPase catalyses the conversion of inosine triphosphate (ITP) to inosine monophosphate (IMP), and pyrophosphate, so the ITP does not accumulate in normal cells. There are two single nucleotide polymorphisms (SNPs) in ITPA gene, located on chromosome 20 (Simone et al., 2013). These two ITPA polymorphisms are associated with reduced ITPase activity resulting in accumulation of ITP in red blood cells (RBCs) and subsequent hemolysis (Von et al., 2008 and Tanaka et al., 2012). RBV can be incorporated into erythrocytes, where it undergoes phosphorylation to its active forms through adenosine kinase. The RBV triphosphate conjugates cannot cross the erythrocyte cell membrane and accumulate in the intracellular compartment, causing oxidative damage and leading to haemolysis (Kuehn, 2014). RBV causes the depletion of ATP which is followed by guanosine triphosphate (GTP) deficiency in RBCs and causes RBC lysis (De Franceschi et al., 2000). 
Accumulated ITP instead of RBV triphosphate in ITPase-deficient patients would play a great role for compensating the depletion of ATP, and prevention of oxidative reactions and $\mathrm{RBC}$ lysis (Thompson et al., 2011). The ITPase deficiency causes accumulation of ITP in RBCs that may compete with RBV triphosphate, thereby protecting from RBV-induced haemolysis (Sakamoto et al., 2010; Hitomi et al., 2011; Kim et al., 2013 and Peltenburg et al., 2015). Although ITPase deficiency is protective against anemia, it has been associated with a greater decline in platelet count during RBV therapy (Rembeck et al., 2014). In agarose gel electrophoresis, Agarose is usually used in gel between $0.7 \%$ and $3 \%$, which determines the pore size. Lower concentrations result in larger pore sizes, whereas higher concentrations result in smaller pore sizes. Agarose gels are generally used to separate larger nucleic acid molecules such as DNA or RNA because the pore sizes are large enough for these molecules to pass through the gel. (Ashok et al., 2017).

The aim of this study was to investigate the association between inosine triphosphatase (ITPase) activity and the degree of anemia occurring during ribavirin theraby in hepatitis $\mathrm{C}$ virus (HCV)-infected patients.

\section{Materials and Methods}

\section{Collection of samples:}

Serum, plasma or whole blood samples were prepared by collecting a blood sample from the vein. Blood was collected in serum separation tube. Samples were allowed standing for 15 to $30 \mathrm{~min}$ at room temperature, and then centrifuged at $3000 \mathrm{rpm}$ for $10 \mathrm{~min}$. The serum was harvested by a micropipette into an Eppendorf tubes and stored at $-20^{\circ} \mathrm{C}$ for assay later on the same day. Blood samples were collected in heparinized tube, mixed gently without shaking, and then centrifuged at 3000 rpm for $10 \mathrm{~min}$. Plasma samples were then separated by a micropipette into an eppendorf tubes and stored at $-20^{\circ} \mathrm{C}$ for further analysis. Blood samples were collected in heparinized or EDTA tubes; mixed gently with gentle shaking to mix blood with anti- clotting factor. The predicted inosine triphosphate pyrophosphatase (ITPase) activity was studied. Serum HCV RNA determined using a qualitative polymerase chain reaction (PCR) assay (Amplicor HCV version 2.0, Roche Molecular Systems, Pleasanton, CA, USA). Liver function tests, CBC, Fasting blood sugar and INR were measured by the automated Cobas C311. TSH, AFP and HBsAg were measured by the automated Cobas A411. Two milliliters of blood were put into vaccutainers containing ethylene diamine tetra-acetic acid (EDTA) for DNA extraction and analysis of ITPA polymorphism using Real time PCR-assay. Total genomic DNA of patients was extracted using Qiagen extraction kit. Rotor-Gene 6000 (QIAGEN, ABI system, USA).

\section{RNA extraction Procedure:}

Centrifuge $50-500 \mu \mathrm{L}$ of blood for $5 \mathrm{~min}$ then Resuspend the pellet in $600 \mu \mathrm{L}$ of Lysis Buffer, mix well by vortexing. Add $450 \mu \mathrm{L}$ of ethanol (96-100\%) and mix well. Transfer half of the prepared lysate to a column inserted in a collection tube. Centrifuge the column for $1 \mathrm{~min}$ at $12,000 \times \mathrm{g}(\sim 11,000 \mathrm{rpm})$. Discard the flow through solution and reassemble the column and collection tube. Transfer remaining lysate into the column and centrifuge as before. Discard the collection tube containing the flowthrough solution. Place the column into a new 2 $\mathrm{mL}$ collection tube (included). Add $700 \mu \mathrm{L}$ of Wash Buffer WB 1 (with ethanol added). Centrifuge for $1 \mathrm{~min}$ at $12,000 \times \mathrm{g}(\sim 11,000$ $\mathrm{rpm})$. Discard the flow-through and place the purification column back into the collection tube. Add $500 \mu \mathrm{L}$ of Wash Buffer 2 (with ethanol added) to the purification column. Centrifuge for $1 \mathrm{~min}$ at $12,000 \times \mathrm{g}(\sim 11,000$ $\mathrm{rpm}$ ). Add $500 \mu \mathrm{L}$ of Wash Buffer 2 (with ethanol added) to the purification column. Centrifuge for $2 \mathrm{~min}$ at $12,000 \times \mathrm{g}(\sim 11,000$ rpm). Empty the collection tube. Place the purification column back into the tube and respin the column for $1 \mathrm{~min}$ at maximum speed $(\geq 20,000 \times \mathrm{g}, \geq 14,000 \mathrm{rpm})$. Discard the collection tube containing the flow-through solution and transfer the purification column to an RNase-free $1.5 \mathrm{~mL}$ micro centrifuge tube. Add $50 \mu \mathrm{L}$ of nuclease-free water to the center of the purification column membrane and centrifuge for $1 \mathrm{~min}$ at $12,000 \times \mathrm{g}(\sim 11,000$ $\mathrm{rpm})$. Discard the purification column. Use the purified RNA immediately in downstream applications or store at $-20^{\circ} \mathrm{C}$ until use. Keep the RNA on ice after extraction and while working with it. 


\section{Generation of cDNA Procedures:}

The first-strand cDNA was generated for use in two-step RT-PCR. Add into sterile, nucleasefree tube on ice $5 \mu \mathrm{g}$ of Template RNA, $0.2 \mu \mathrm{g}$ Primer and complete to $12.5 \mu \mathrm{L}$ DEPC-treated water then centrifuge and place on ice. Add 4 $\mu \mathrm{L}$ buffer, $0.5 \mu \mathrm{L}$ RNase Inhibitor, $2 \mu \mathrm{L}$ dNTP, $1 \mu \mathrm{L}$ Reverse Transcriptase then Mix gently and centrifuge. (Gerard and D'Alessio, 1993).

\section{Real-time PCR:}

Maxima SYBR Green qPCR Master Mix (2X), ROX Solution provided was used. Primer design for qPCR is one of the most important factors to obtain efficient amplification and to avoid the formation of primer dimers. Sequences of the primers which were used in the reaction are Forward (TCA TTG GTG GGG AAG AAG ATC) and Reverse (AAG CTG CCA AAC TGC CAA A) (Longo et al., 1990).

\section{Detection of PCR products:}

PCR products are generally detected by agarose gel electrophoresis using Fifteen $\mu \mathrm{l}$ of amplified product and mixed with $4 \mu \mathrm{l}$ of loading buffer $(0.1 \%$ bromophenol blue, $1 \%$ SDS and 50\% sucrose) loaded into the wells of $2 \%$ prepared agarose and fractionated in TAE buffer (40 mMTris-HCL, 20mM acetic acid and $1 \mathrm{mM}$ EDTA) in a submarine agarose electrophoresis unit (HE 33, from Hoefer S. F., CA and USA). The gels were stained with ethidium bromide $(0.5 \mu \mathrm{g} / \mathrm{ml}$ in running buffer $)$ for each agarose. The DNA marker, kilo base pair (kbp) (Fermentas, life science). After electrophoresis, agarose gel was visualized under UV light using the transilluminator FBTIV-88 (from fisher scientific Pittsburg USA). Gels were pictured using the digital camera. (Ashok et al., 2017).

\section{Results}

There were 25 males (50\%) and 25 females $(50 \%)$ out of 50 patients. The age of the patients ranged (21-63) years with mean \pm SE (50.4 \pm 1.57). Baseline characteristics also are summarized with laboratory investigations before treatment: complete blood count, bilirubin, liver enzymes, INR, albumin, Alpha
Fetoprotein and HCV RNA in serum or plasma by a sensitive qualitative and quantitative molecular method. Also, the dose of treatment ranged $(400-1,200) \mathrm{mg} / \mathrm{kg}$ with mean $\pm \mathrm{SE}(844$ \pm 22.34). Table 1 shows the demographic, clinical, biochemical and virological characteristics of patients.

Table 1: Basic characteristic and laboratory results of patients before treatment with Mean and standard error (SE).

\begin{tabular}{lcc}
\hline Variables before treatment & Mean & SE \\
\hline HB & 12.86 & 0.28 \\
WBCs & 6.09 & 0.37 \\
RBCs & 4.62 & 0.07 \\
Plt & 182.76 & 12.05 \\
Alb & 4.08 & 0.08 \\
SGOT(AST) & 46.3 & 4.16 \\
SGPT(ALT) & 47.3 & 4.37 \\
BIL & 0.84 & 0.04 \\
INR & 1.16 & 0.03 \\
Dose & 844 & 22.34 \\
AFP & 5.45 & 0.59 \\
FBS & 106.2 & 6.25 \\
RNA quantitative & 1470126.8 & 245434.3 \\
TSH & 2.46 & 0.4 \\
Age (years) & 50.4 & 1.57 \\
Height & 162.86 & 1.25 \\
Weight & 83.5 & 2.79 \\
\hline Ablreviations:
\end{tabular}

Abbreviations: HB: Hemoglobin; WBCs: White blood Cells; RBCs: Red blood cells; Plt: Platelets; Alb: Albumin; AST: Aspartate aminotransferase; ALT: Alanine aminotransferase; BIL: Bilirubin; INR: International Normalized Ratio; AFP: Alfa fetoprotein; FBS: Fasting blood sugar; RNA: Ribonucleic acid and TSH: Thyroid stimulating hormone.

Baseline characteristics before treatment (T0), one week after treatment (T1), one month after treatment (T2) and 3 months after treatment (T3) of all patients are summarized in Table 2. Data of all patients in different periods were analyzed using univariate analysis.

Concerning hemoglobin, there was a significant decrease between $\mathrm{T} 0$ and $\mathrm{T} 3$ $\left(\mathrm{P} 3=0.007^{*}\right.$, table 2 and Figure1). In Concerning Red blood cells, there was a significant decrease between $\mathrm{T} 0$ and $\mathrm{T} 3$ (P3 $=0.006^{*}$, table2 and Figure2). In White blood cells, there was an increase in WBCs after one week and after one month of treatment then the reduction in the count occurred after 3 months of treatment Figure3. Platelets count increased after a week and after one month of treatment then decreased after 3 months of treatment Figure 4. 
Table 2: Basic characteristics and comparison of laboratory results after and before treatment. Values represent mean \pm SE.

\begin{tabular}{lccccl}
\hline & T0 & T1 & T2 & T3 & Post hoc Tukey test \\
\hline HB & $12.86 \pm 0.28$ & $12.41 \pm 0.24$ & $12.13 \pm 0.25$ & $11.67 \pm 0.26$ & $\mathrm{P} 1=0.607 ; \mathrm{P} 2=0.19 ; \mathrm{P} 3=0.007^{*}$ \\
WBCs & $6.09 \pm 0.37$ & $6.41 \pm 0.3$ & $6.38 \pm 0.31$ & $5.65 \pm 0.29$ & $\mathrm{P} 1=0.890 ; \mathrm{P} 2=0.917 ; \mathrm{P} 3=0.775$ \\
RBCs & $4.62 \pm 0.07$ & $4.5 \pm 0.08$ & $4.35 \pm 0.09$ & $4.24 \pm 0.09$ & $\mathrm{P} 1=0.716 ; \mathrm{P} 2=0.087 ; \mathrm{P} 3=0.006^{*}$ \\
Plt & $182.76 \pm 12.05$ & $194.26 \pm 15.85$ & $195.44 \pm 16.21$ & $187.51 \pm 15.64$ & $\mathrm{P} 1=0.949 ; \mathrm{P} 2=0.933 ; \mathrm{P} 3=0.996$ \\
Alb & $4.08 \pm 0.08$ & $3.93 \pm 0.11$ & $3.96 \pm 0.07$ & $4.03 \pm 0.07$ & $\mathrm{P} 1=0.585 ; \mathrm{P} 2=0.712 ; \mathrm{P} 3=0.961$ \\
SGOT & $46.3 \pm 4.16$ & $38.4 \pm 3.32$ & $26.74 \pm 1.52$ & $27.6 \pm 1.4$ & $\mathrm{P} 1=0.208 ; \mathrm{P} 2<0.001^{*} ; \mathrm{P} 3<0.001^{*}$ \\
SGPT & $47.3 \pm 4.37$ & $39.02 \pm 3.61$ & $25.8 \pm 1.59$ & $25.52 \pm 1.66$ & $\mathrm{P} 1=0.225 ; \mathrm{P} 2<0.001^{*} ; \mathrm{P} 3<0.001^{*}$ \\
BIL & $0.84 \pm 0.04$ & $0.88 \pm 0.05$ & $0.85 \pm 0.05$ & $0.76 \pm 0.03$ & $\mathrm{P} 1=0.906 ; \mathrm{P} 2=0.991 ; \mathrm{P} 3=0.639$ \\
INR & $1.16 \pm 0.03$ & $1.14 \pm 0.03$ & $1.16 \pm 0.03$ & $1.12 \pm 0.02$ & $\mathrm{P} 1=0.960 ; \mathrm{P} 2=1.0 ; \mathrm{P} 3=0.737$ \\
Dose & $844 \pm 22.34$ & - & $804 \pm 23.90$ & $787.76 \pm 25.69$ & $\mathrm{P} 2=0.465 ; \mathrm{P} 3=0.226$ \\
\hline
\end{tabular}

P1: T0 vs. T1; P2: T0 vs. T2; P3: T0 vs. T3

One-Way ANOVA test, * Significant $\mathrm{P}<0.05$

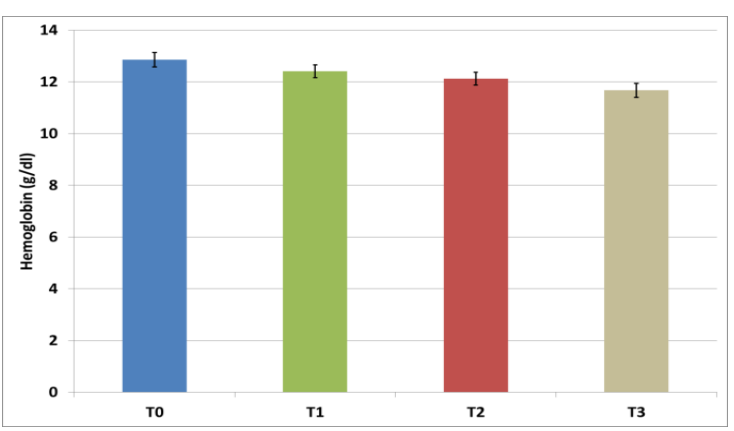

Figure 1. Hemoglobin concentration (g/dl) in $\mathrm{HCV}$ patients before and after treatment. Data are represented by means $\pm \mathrm{SE}$.

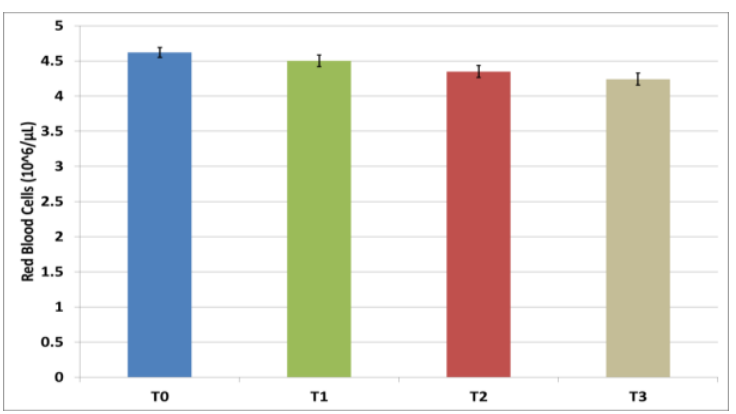

Figure 2. Red blood cells count $\left(10^{6} / \mu \mathrm{l}\right)$ in $\mathrm{HCV}$ patients through 3 months of treatment. Data are represented by means \pm SE.

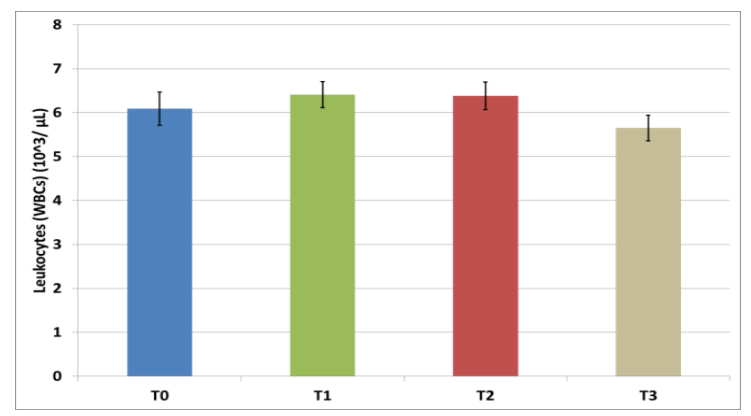

Figure 3. White blood cells count $\left(10^{3} / \mu \mathrm{l}\right)$ in $\mathrm{HCV}$ patients through 3 months of treatment. Data are represented by means \pm SE.

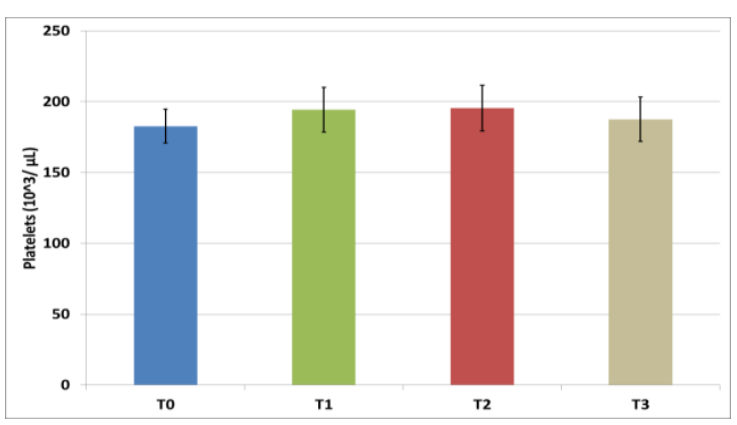

Figure 4. Platelets count $\left(10^{3} / \mu \mathrm{l}\right)$ in $\mathrm{HCV}$ patients through 3 months of treatment. Data are represented by means $\pm \mathrm{SE}$.

In terms of liver functions, there was a significant decrease in activity of AST (A) and ALT (B) between (T0, T2) and (T0, T3) respectively $(\mathrm{P} 2<0.001 *, \quad \mathrm{P} 3<0.001 *)$ and (P2<0.001*, P3<0.001*), Fig. 5 (A) and (B). Total bilirubin Fig. 6 as well as Albumin Fig. 7 did not show any significant differences .Data are represented by means $\pm \mathrm{SE}$.

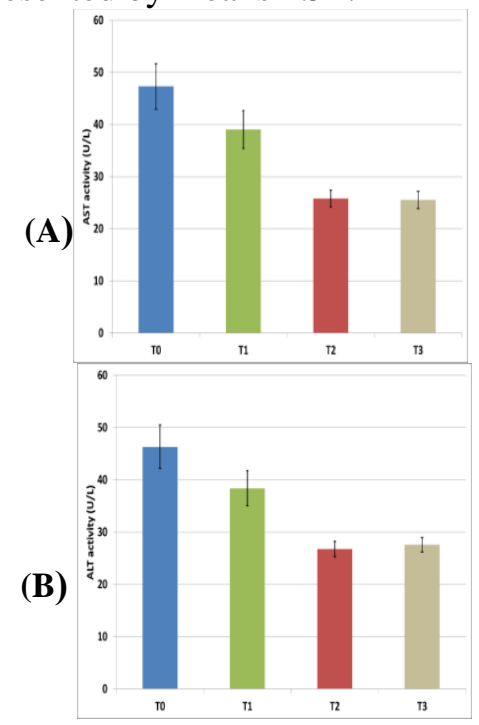

Figure 5. Activity of AST in U/L (A) and activity of ALT in U/L (B) in HCV patients through 3 months of treatment. Data are represented by means \pm SE. 


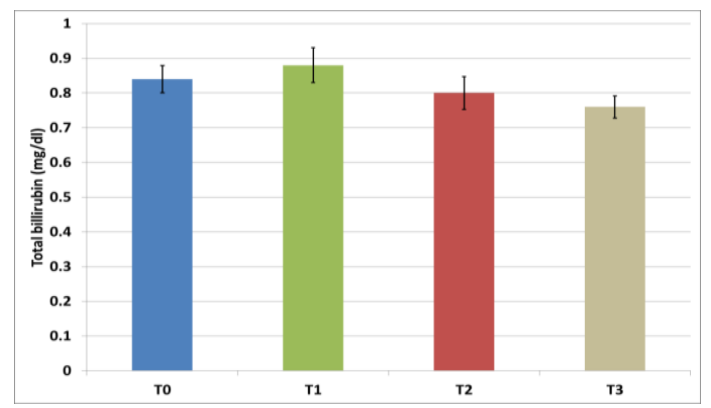

Figure 6. Concentration of total bilirubin $\mathrm{mg} / \mathrm{dl}$ in $\mathrm{HCV}$ patients through 3 months of treatment. Data are represented by means \pm SE.

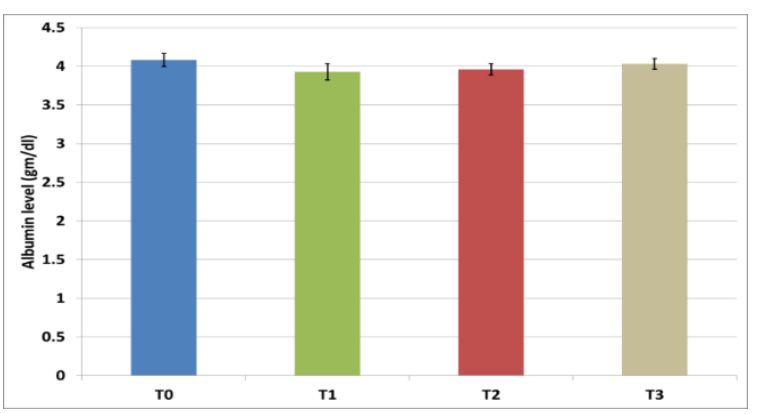

Figure 7. Concentration of serum albumin $\mathrm{g} / \mathrm{dl}$ in HCV patients through 3 months of treatment. Data are represented by means \pm SE.

INR did not show any significant differences in HCV patients through 3 months of treatment Fig.8.

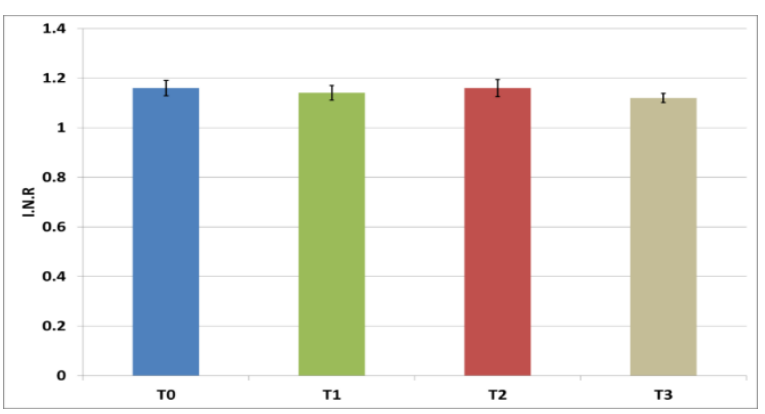

Figure 8. INR values in $\mathrm{HCV}$ patients through 3 months of treatment. Data are represented by means $\pm \mathrm{SE}$.

ITPA gene expression before and after treatment is shown in table 3, Figure 9. The activation of ITPA gene decrease significantly after one month treatment as compared to before treatment $(\mathrm{P}<0.001 *)$.

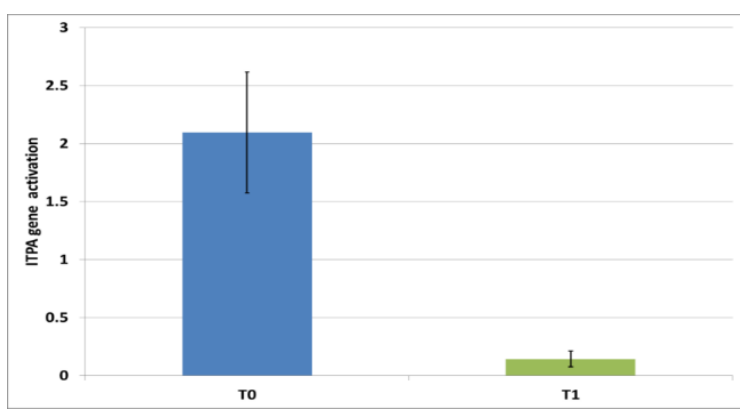

Figure 9. ITPA gene activation before and after one month of treatment. Data are represented by means \pm SE.

There was a reduction in ITPase activity resulting in RBCs hemolysis. The rest of variables did not show any significant through reduction of ITPA gene activity.

There was an inverse relationship between gene and dose resulted in reducing gene activity after one month of treatment. The other variables did not show any significant differences after treatment.

There were no differences between types of treatment. The table shows Mean \pm SE of two types of treatment and their relations with hemoglobin after and before treatment.

\section{PCR amplification of ITPA gene}

By using ITPA gene-specific primer, an amplicone with about 250 bp was amplified in PCR reaction (Figure 10). The PCR products were electrophoresis in $1.5 \%$ agarose gel. The activity of the ITPA gene is proportional to the intensity of illumination of the bands. ITPA gene with high activity had strong illuminated bands, unlike the low activation of ITPA gene had weak illuminated bands Fig.10.

Table 3: Mean \pm standard error and median of ITPA gene expression before and after one month of treatment.

\begin{tabular}{|c|c|c|c|c|c|}
\hline & & T0 & T1 & & $\mathbf{P}$ \\
\hline \multirow[t]{2}{*}{ ITPA } & $\begin{array}{l}\text { Mean } \pm \text { Std. } \\
\text { Error }\end{array}$ & $2.097 \pm 0.521$ & $0.143 \pm 0.068$ & $\mathrm{t}=3.962$ & $<0.001 *$ \\
\hline & $\begin{array}{l}\text { Median }(\min - \\
\max )\end{array}$ & $\begin{array}{l}0.366 \\
(0-18.38)\end{array}$ & $\begin{array}{l}0.0023 \\
(0-2.64)\end{array}$ & $Z=5.712$ & $<0.001 *$ \\
\hline
\end{tabular}

Paired t-test; Z: Wilcoxon sign rank test * Significant $\mathrm{P}<0.05$ 
(Table 4) Correlations of serum ITPA gene with hematological and biochemical parameters in studied patients before treatment.

\begin{tabular}{lcc}
\hline & \multicolumn{2}{c}{ ITPA gene before treatment } \\
\cline { 2 - 3 } & $\mathrm{r}$ & $\mathrm{P}$ \\
\hline HB & -0.227 & 0.138 \\
WBCs & -0.007 & 0.963 \\
RBCs & -0.404 & $0.006^{*}$ \\
Plt & -0.042 & 0.785 \\
Alb & -0.041 & 0.791 \\
SGOT & -0.077 & 0.621 \\
SGPT & -0.192 & 0.212 \\
BIL & -0.128 & 0.406 \\
INR & 0.356 & $0.018^{*}$ \\
Dose & -0.072 & 0.642 \\
AFP & 0.064 & 0.683 \\
FBS & -0.004 & 0.980 \\
RNA quantitative & 0.119 & 0.441 \\
TSH & 0.009 & 0.952 \\
Age & 0.161 & 0.296 \\
Height & 0.011 & 0.944 \\
Weight & -0.012 & 0.938 \\
\hline Spearman's
\end{tabular}

Spearman's correlation co-efficient

* Significant $\mathrm{P}<0.05$

Table 5: Correlations of serum ITPA gene with hematological and biochemical parameters in studied patients after one month of treatment.

\begin{tabular}{lcc}
\hline & \multicolumn{2}{c}{ ITPA gene After month } \\
\cline { 2 - 3 } & r & P \\
\hline HB & -0.207 & 0.177 \\
WBCs & -0.007 & 0.961 \\
RBCs & -0.301 & $0.047^{*}$ \\
PIt & -0.059 & 0.705 \\
Alb & -0.173 & 0.261 \\
SGOT & -0.025 & 0.871 \\
SGPT & -0.163 & 0.291 \\
BIL & 0.040 & 0.797 \\
INR & 0.090 & 0.562 \\
Dose & -0.308 & $0.044^{*}$ \\
\hline
\end{tabular}

Spearman's correlation co-efficient

* Significant $\mathrm{P}<0.05$

(Table 6) Correlations of treatment with hemoglobin before, after one week, after one month and after 3 months of treatment with statistically significant decrease in hemoglobin.

\begin{tabular}{|c|c|c|c|c|}
\hline & $\begin{array}{c}\text { SOF/DAC/RB } \\
\text { V } \\
(\mathbf{n}=\mathbf{3 0})\end{array}$ & $\begin{array}{l}\text { Qurevo/RBV } \\
(\mathbf{n}=\mathbf{2 0})\end{array}$ & $\mathbf{t}$ & $\mathbf{P}$ \\
\hline $\begin{array}{l}\text { T0- } \\
\text { HB }\end{array}$ & $12.86 \pm 1.92$ & $12.85 \pm 2.087$ & 0.017 & 0.986 \\
\hline $\begin{array}{l}\text { T1- } \\
\text { HB }\end{array}$ & $12.227 \pm 1.741$ & $12.675 \pm 1.704$ & 0.899 & 0.373 \\
\hline $\begin{array}{l}\text { T2- } \\
\text { HB }\end{array}$ & $12.105 \pm 1.785$ & $12.155 \pm 1.709$ & 0.098 & 0.922 \\
\hline $\begin{array}{l}\text { T3- } \\
\text { HB }\end{array}$ & $11.7 \pm 2.034$ & $11.625 \pm 1.612$ & 0.138 & 0.891 \\
\hline
\end{tabular}

t: student t-test, ${ }^{*}$ Significant $\mathrm{P}<0.05$

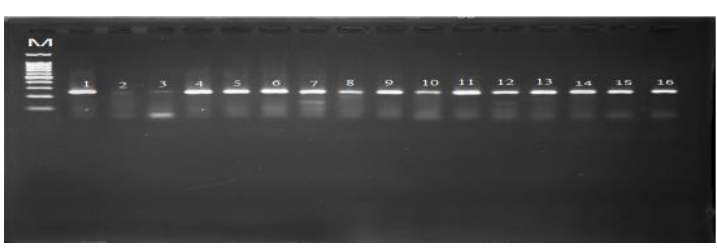

Figure 10. Reverse Trascriptase PCR (RT-PCR) amplification of the ITPA gene; Lane M: $100 \mathrm{bp}$ DNA ladder, Lane 1 indicates to control, lanes (2, 3, $8,10,12)$ are weak illuminated bands that indicate to the low activity of ITPA gene after one month of treatment and lanes $(4,5,6,11,13)$ are strong illuminated bands that indicate to the high activity of ITPA gene before treatment in HCV patients.

\section{Discussion}

The present study indicated to the hematological abnormalities in patients with hepatitis $\mathrm{C}$ virus treated with ribavirin therapy and their relationship with ITPA gene expression. One of the most important reasons for decreased adherence to treatment is the development of side effects such as multiple hematological abnormalities including neutropenia, anemia, and thrombocytopenia (McHutchison et al., 2007 and Reau et al., 2008). It demonstrates that genotype 1 is an important factor for development of hematological abnormalities in patients with hepatitis $\mathrm{C}$ receiving treatment. The antiviral treatment is the standard of care for treatment of chronic hepatitis C (Kowdley et al., 2005). Genotype 1 has been shown in previous studies to be a factor in influencing viral response rates to treatment. This study provides evidence to clinicians that patients with genotype 1 infection may need a closer follow-up during treatment for hepatitis $\mathrm{C}$ for development of hematological abnormalities. Other factors associated with hematological abnormalities include a low baseline platelet count as well as a low baseline hemoglobin count. This large cohort study in a real world setting found that genetic polymorphisms in the ITPA gene, resulting in ITPase deficiency, were associated with less $\mathrm{Hb}$ decline during RBV therapy among Caucasian patients with chronic HCV infection. Patients with normal ITPase activity were at higher risk to undergo dose reductions of RBV and receive blood transfusions. Patients with ITPase deficiency experienced lower declines in $\mathrm{Hb}$ concentration than patients with normal ITPase activity during the first four weeks of antiviral treatment. As expected, 
besides the presence of normal ITPase activity, RBV dose was also associated with a significant decline in $\mathrm{Hb}$ at week 4 . The results of the present study confirm observations described in previous studies (Thompson et al., 2011; Holmes et al., 2014 and Rembeck et al., 2014). In contrast, another study among 546 patients showed no association between ITPase deficiency and RBV levels $(\mathrm{p}=0.11)$ (Holmes et al., 2014). The studies among patients with $\mathrm{HCV}$ genotype 2 and 3 found no association between the ITPase activity and the need for RBV dose reductions (Thompson et al., 2011 and Rembeck et al., 2014). Combination therapy with ribavirin for the treatment of patients with chronic $\mathrm{HCV}$ is widely used as a standard regimen, because several studies attest to its prominent efficacy and the acceptable tolerability of ribavirin. (Reichard et al., 1997; McHutchinson et al., 1998 and Poynard et al., 1998). However, the most notable side effect of ribavirin is reversible hemolytic anemia, (Bodenheimer et al., 1997; Davis et al., 1997; Reichard et al., 1997; McHutchinson et al., 1998; Poynard et al., 1998; Tappero et al., 1998; Maddrey, 1999; McHutchison et al., 1999 and Van et al., 2001) which is observed as a decrease in $\mathrm{Hb}$ levels (2-4) weeks after the beginning of the combination therapy (Maddrey, 1999) and this agreed with our results. The ribavirin-induced anemia can increase fatigue, has a demonstrable effect on quality of life, and is a frequent indication for dose reduction of ribavirin. Therefore, careful monitoring should be done during the treatment, especially during the first 4 weeks. RBV induces dose-related hemolytic anemia that impairs the patients' quality of life and frequently requires a dosage reduction, which may be serious in difficult patients, such as the elderly and cirrhotic patients. This adverse reaction has been reported in more than $30 \%$ (Stickel et al., 2012) of the cases treated with combination therapy, more frequent during the administration of triple combination therapy with RBV and telaprevir or boceprevir (Piccinino et al., 2007) and less frequent in DAA/RBV regimens (Coppola et al., 2014 and Cheung et al., 2016). Erythrocyte hemolysis is considered the main cause of RBV-induced anemia (Younossi et al., 2016). By reducing adenosine triphosphate (ATP) levels in human erythrocytes, RBV induces a guanosine triphosphate (GTP) depletion followed by the inhibition of the ATP-dependent oxidative metabolism, membrane damage and premature hemolysis of erythrocytes (De Franceschi $\boldsymbol{e t}$ al., 2000). In patients with reduced ITPase activity, however, inosine triphosphate (ITP) accumulates in erythrocytes (Sumi et al., 2002 and Arenas et al., 2007), replacing the GTP activity and producing adenosine monophosphate (AMP) (Hitomi et al., 2011), thus avoiding the inhibition of the ATPdependent oxidative metabolism and erythrocyte hemolysis. Therefore, RBVinduced anemia seems primarily to be due to the reduced levels of ATP in erythrocytes consequent to the effect of the drug on GTP (Jimmerso et al., 2016), and resistance against $\mathrm{RBV}$-related anemia is due to a reduced ITPA activity (Thompson et al., 2011).

\section{Conclusion}

The patients with deficiency in ITPA gene expression showed a decline in hemoglobin during the first month of treatment. ITPA polymorphisms increase the likelihood of developing hemolytic anemia for $\mathrm{HCV}$-infected patients on RBV-based therapy, suggesting the utility of screening for ITPA polymorphisms to avoid hematological toxicity and increase adherence to RBV-based therapy.

\section{References}

Arenas, M. ; Duley, J. ; Sumi, S.; Sanderson, J. and Marinaki, A. (2007): The ITPA c.94C >A and g.IVS2+21A $>C$ sequence variants contribute to missplicing of the ITPA gene. Biochim Biophys Acta. (1772): 96-102.

Ashok, K. M. ; Munna, L. Y. and Suman, C. (2017): Gel Electrophoresis of Proteins and Nucleic Acids. Springer Nature Singapore Pte Ltd. 978981.

Bodenheimer, H. C.; Lindsay, K. L.; Davis, G. L.; Lewis, J. H. ; Thung, S. N. and Seeff, L. B. (1997): Tolerance of oral ribavirin treatment of chronic hepatitis $\mathrm{C}$ : a multicenter trial. Hepatology. (26): 473-478.

Cheung, M. C. ; Alex, J. W. ; Benjamin, E. H. ; Suman, V.; John, M. ; David, J. M. ; Ashley, B. ; William, T. H. G. ; Douglas, C. M. ; Kosh, A. ; Graham, R. F. and William, L. I. (2016): Outcomes after successful direct acting antiviral therapy for patients with chronic hepatitis $\mathrm{C}$ and decompensated cirrhosis. J Hepatology. (16): 30314-30322. 
Coppola, N. ; Pisaturo, M. ; Sagnelli, C. ; Sagnelli, E. and Angelillo, I. (2014): Peg-interferon plus ribavirin with or without boceprevir or telaprevir for HCV genotype 1: a meta-analysis on the role of response predictors. PLoS One.(9): e94542.

Davis, G. L. ; Esteban-Mur, R. ; Rustgi, R. ; Hoefs, J. ; Gordon, S. C. ; Trepo, C. ; Shiffman, L. M. ; Zeuzem, S. ; Craxi, A. ; Ling, M. H. and Albrecht, J. (1998): Interferon alfa-2b alone or in combination with ribavirin for the treatment of relapse of chronic hepatitis C. N Engl J Med. (339): 1493-1499.

De Franceschi, L. ; Fattovich, G. ; Turrini, F. ; Ayi, K. ; Brugnara, C. ;Manzato, F. ; Noventa, F. ; Stanzial, A. M. ; Solero, P. and Corrocher, R. (2000): Hemolytic anemia induced by ribavirin therapy in patients with chronic hepatitis $C$ virus infection: role of membrane oxidative damage. Hepatology. 31(4): 997-1004.

Fellay, J. ; Alexander, J. T.; Dongliang, G. ; Curtis, E. G. ;Thomas, J. U. ; Kevin, V. S. ; Latasha, D. L. ; Ping, Q. ; Arthur, H. B. ; Mark, W. ; Amelia, W. ; Andrew, J. M. ; Clifford, B. ; Janice, A.; Mark, S. and John, G. M. (2010): ITPA gene variants protect against anemia in patients treated for chronic hepatitis C. Nature. 464 (7287): 405408.

Fried, M. W. (2002): Side effects of therapy of hepatitis $\mathrm{C}$ and their management. Hepatology. (36): S237-244.

Gerard, G. F. and D'Alessio, J. M. (1993): Methods in Molecular Biology. Humana Press. 73-93.

Hitomi, Y. ; Cirulli, E. T. ; Fellay, J. ; McHutchison, J. G. ; Thompson, A. J. ; Gumbs, C. E. ; Shianna, K. V. ; Urban, T. J. and Goldstein, D. B. (2011): Inosine triphosphate protects against ribavirininduced adenosine triphosphate loss by adenylosuccinate synthase function. Gastroenterology. 140 (4): 1314-1321.

Holmes, J. A. ; Stuart, K. R. ; Rachel, J. A. ; Gregory, J. D. ; William, S. ; Geoffrey, W. M. ; Darrell, H. C. ; Wendy, S. C. ; Martin, D. W. ; Sara, B. ; Kumar, V. ; Vijaya, S. ; Paul, V. D.; Scott, D. B. ; Gail, V. M. and Alexander, J. T. (2014): ITPA genotype protects against anemia during peginterferon and ribavirin therapy but does not influence virological response. Hepatology. 59 (6): 2152-2160.

Jagdish, S. N. ; Gowtham, A. R. ; Deepti, B. ; Prashant, K. P. and Laura, M. A. (2010): Predictors of hematological abnormalities in patients with chronic hepatitis $\mathrm{C}$ treated with interferon and ribavirin. Ann Hematol. (89): 121-125.

Jimmerson, L. C. ; Thomas, J. ; Aimee, T. ; Fafa, B. ; Shyam, P. K. ; Eric, G. M. ; Zayani, S. ; Jacob, A. ; Ariel, H. and Jennifer, B. J. (2016): Variant ITPA phenotypes are associated with increased ribavirin triphosphate levels. J Clin Pharmacol. (57): 118-124.

Kim, J. S. ; Ahn, S. M. ; Young, K. J. ; Oh, S. K. ; Yun, S. K. ; Duck, J. C. and Ju, H. K. (2013): The impact of inosine triphosphatase variants on hemoglobin level and sustained virologic response of chronic hepatitis $\mathrm{C}$ in Korean. $\mathrm{J}$ Korean Med Sci. (28): 1213-1219.

Kuehn, B. M. G. (2014): new HCV drugs should go to sickest patients. JAMA. 312(11): 1084-1085.

Kowdley, K. V. (2005): Hematologic side effects of interferon and ribavirin therapy. $\mathrm{J}$ Clin Gastroenterol. (39): S3-8.

Lavanchy, D. (2009): The global burden of hepatitis C. Liver Int. (29): 74-81.

Longo, M. C. ; Berninger, M. S. and Hartley, j. L. (1990): Use of uracil DNA glycosylase to control carry-over contamination in polymerase chain reactions. National Center for Biotechnology information. (93): 125-128

Maddrey, W. C. (1999): Safety of combination interferon alpha2b/ribavirin therapy in chronic hepatitis C-related and treatment naïve patients. Semin Liver Dis. (19): 67- 75.

Manns, M. P. ; McHutchison, J. G. ; Gordon, S. C. ; Rustgi, V. K. ; Shiffman, M. ; Reindollar, R. ; Goodman, Z. D. ; Koury, K. ; Ling, M. and Albrecht, J. K. (2001): Peginterferon alfa-2b plus ribavirin compared with interferon alfa- $2 b$ plus ribavirin for initial treatment of chronic hepatitis C. Lancet. (358): 958-965.

McHutchison, J. G. and Poynaud, T. (1999): Combination therapy with interferon plus ribavirin for the initial treatment of chronic hepatitis C. Semin Liver Dis. (19): 57-65.

McHutchison, J. G. ; Gordon, S. C. ; Schiff, E. R. ; Shiffman, M. L. ; Lee, W. M. ; Rustgi, V. K. ; Goodman, Z. D .; Ling, M. H. ; Cort, S. and Albrecht, J. K. (1998): Interferon alfa-2b alone or combination with ribavirin as initial treatment for chronic hepatitis C. NewEngl J Med.(339):1485-1492.

McHutchison, J. G. ; Michael, M. ; Keyur, P. ; Thierry, P. ; Karen, L. ; Lindsay, C. ; Trepo, J. ; Dienstag, W. M. ; Lee, C. ; Mak, J. and Garaud, J. (2002): For the International Hepatitis Interventional Therapy Group Adherence to combination therapy enhances sustained response in genotype-1-infected patients with chronic hepatitis C. Gastroenterology. (123): 1061-1069.

McHutchison, J. G. ; Michael, P. M. ; Robert, S. B. J. ; Reddy, K. R. ; Mitchell, L. S. and John, B. W. (2007): Strategies for managing anemia in hepatitis $\mathrm{C}$ patients undergoing antiviral therapy. Am J Gastroenterology. (102): 880-889.

Mulhall, B. P. and Younossi, Z. (2005): Impact of 
adherence on the outcome of antiviral therapy for chronic hepatitis C. J Clin Gastroenterol. (39): S23.

Ong, J. P. and Younossi, Z. M. (2004): Managing the hematologic side effects of antiviral therapy for chronic hepatitis $\mathrm{C}$ : anemia, neutropenia, and thrombocytopenia. Cleve Clin J Med. (71): S1721.

Peltenburg, N. C. ; Jaap, A. B. ; Wim, H. M. V. ; Robert, J. de K. ; Mathie, P. G. L. ; Jörgen, B. and Annelies, V. (2015): Inosine triphosphate pyrophosphohydrolase activity: More accurate predictor for ribavirin-induced anemia in hepatitis $\mathrm{C}$ infected patients than ITPA genotype. Clin Chem Lab Med. (53): 2021-2029.

Piccinino, F. and Coppola, N. (2007): Antiviral treatment of HCV-related cirrhosis. Dig Liver Dis. (39): S96-S101.

Poynard, T. ; Marcellin, P. ; Lee, S. S. ; Niederau, C. ; Minuk, G. S. ; Ideo, G. ; Bain, V. ; Heathcote, J. ; Zeuzem, S. ; Trepo, C. and Albrecht, J. (1998): Randomized trial of interferon alpha-2b plus ribavirin for 48 weeks or for 24 weeks versus interferon alpha- $2 \mathrm{~b}$ plus placebo for 48 weeks for treatment of chronic infection with hepatitis $\mathrm{C}$ virus.Lancet. (352): 1426-1432.

Reau, N. ; Stephanos, J. ; Hadziyannis, D. M. ; Michael, W. F. and Donald, M. J. (2008): Early predictors of anemia in patients with hepatitis $\mathrm{C}$ genotype 1 treated with peginterferon alfa- $2 \mathrm{a}$ (40KD) plus ribavirin. Am J Gastroenterology. (103):1981-1988.

Reichard, O. ; Schvartcs, R. and Weiland, O. (1997): Therapy of hepatitis $\mathrm{C}$ : alpha interferon and ribavirin. Hepatology. (26): 108S-11S.

Rembeck, K. ; Jesper, W.; Kristoffer, H. ; Staffan, N. ; Kristina, N. ; Anna, M. ; Magnus, L. ; Gunnar, N. ; Johan, W. ; Court, P. ; Martti, F. ; Nina, L. ; Mads, R. B. ; Kristine, M. ; Peer, B. C. and Martin, L. (2014): Variants of the inosine triphosphate pyrophosphatase gene are associated with reduced relapse risk following treatment for HCV genotype 2/3. Hepatology. (59): 2131-2139.

Sakamoto, N. ; Yasuhito, T., Mina, N. ;Hiroshi, Y. ; Shuhei, N. ; Nobuyuki, E. ; Seishin, A. ; Yuki, N. ; Sei, K. ; Nao, N. ; Katsushi, T. ; Masao, H. ; Kiyoaki, I. ; Masashi, M. and Mamoru, W. (2010): ITPA gene variant protects against anemia induced by pegylated interferon- $\alpha$ and ribavirin therapy for Japanese patients with chronic hepatitis C. Hepatol Res. (40): 10631071.

Simone, P. D. ; Lucas, R. S. ; Admir, K. ; Carrie, A. B. ; Corinn, E. G. ; Irine, K. ; Luis, A. M. ; Youri, I. P. and Gloria, E. O. B. (2013): The human ITPA polymorphic variant $\mathrm{P} 32 \mathrm{~T}$ is destabilized by the unpacking of the hydrophobic core. J Struct Biol. (182): 197-208.

Sumi, S. ; Anthony, M. M. ; Monica, A. ; Lynette, F. ; Monsor, S. ; David, C. R. ; Swee, L. T. ; Azhar, A. ; Jeremy, S. ; Ronney, A. De. A. ; Anne, H. S. and John, A. D. (2002): Genetic basis of inosine triphosphate pyrophosphohydrolase deficiency. Hum Genet. 111 (4-5): 360-367.

Shintaro, T. ; Akihito, T. ; Tetsuya, H. ; Norio, A. ; Takashi, S. ; Masahiro, K. ; Fumitaka, S. ; Yoshiyuki, S. ; Satoshi, S. ; Yasuji, A. ; Kenji, I. and Hiromitsu, K. (2004): Factors contributing to ribavirin dose reduction due to anemia during interferon alfa2b and ribavirin combination therapy for chronic hepatitis C. J Gastroenterol. (39): 668-673.

Stickel, F. ; Helbling, B. ; Heim, M. ; Geier, A. ; Hirschi, C. ; Terziroli, B. ; Wehr, K. ; De Gottardi, A. ; Negro, F. and Gerlach, T. (2012): Critical review of the use of erythropoietin in the treatment of anemia during therapy for chronic hepatitis C. J Viral Hepat. (19): 77-87.

Tanaka, Y. ; Manabe, A. ; Fukushima, H. ; Suzuki, R. ; Nakadate, K. ; Kondoh, K. ; Nakamura, K. ; Koh, K. ; Fukushima, T. ; Tsuchida, M.; Koike, K. ; Kiyokawa, N. ; Noguchi, E. ; Sumazaki, R. and Komiyama, T. (2012): The activity of the inosine triphosphate pyrophosphatase affects toxicity of 6 mercaptopurine during maintenance therapy for acute lymphoblastic leukemia in Japanese children. Leuk Res. (36): 560-564.

Tappero, G. ; Ballare, M. ; Farina, M. and Negro, F. (1998): Severe anemia following combined alpha-interferon/ribavirin therapy of chronic hepatitis C (letter). Hepatology .(29): 10331034.

Thompson, A. J. ; Rosanna, S. ; Valeria, P. ; Paul, J. C. ; Susanna, N. ; Hans, L. T. ; Keyur, P. ; Andrew, J. M. ; Kevin, V. S. ; Leonardo, M. ; Daniela, P. ; Mario, R. ;Fernando, S. ; Domenico, F. ; David, B. G. ; John, G. M. and Alessandra, M. (2011): Inosine triphosphatase genetic variants are protective against anemia during antiviral therapy for HCV2/3 but do not decrease dose reductions of RBV or increase SVR. Hepatology. 53(2): 389-395.

Van, V. H. ; Delanghe, J. R. ; De Vos, M. and Leroux-Roel, G. (2001): Factors influencing ribavirin-induced hemolysis. J Hepatol. (34): 911-916.

Von, A. N. ; Oellerich, M. and Armstrong, V. W. (2008): Characterization of the inosine triphosphatase (ITPA) gene: Haplotype structure, haplotype-phenotype correlation and promoter function. Ther Drug Monit. (30): 1622.

Younossi, Z. M. ; Maria, S. ; Linda, H. ; Fatema, N. ; Youssef, Y. and Sharon, H. (2016): Adherence 
to treatment of chronic hepatitis $\mathrm{C}$ : from interferon containing regimens to interferon and ribavirin free regimens. Medicine (Baltimore). (95): e4151.

الملخص العربي

عنوان البحث: ارتباط نثاط جين الإتبا بالتثوهات الدموية المستحثة بالعلاج الثنائي في المرضي

نجلاء العرباني ، ناهد عمر، مي علاء الدين علي راشد، مصطفي الثاعر، أحمد عبدالخالق

الملخص العربي

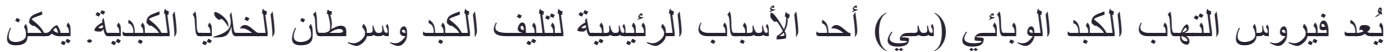

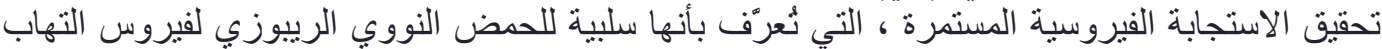

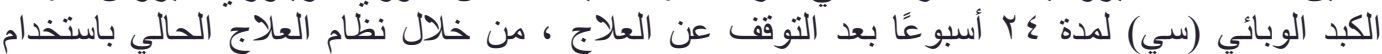

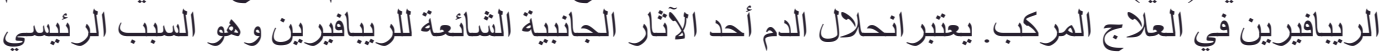

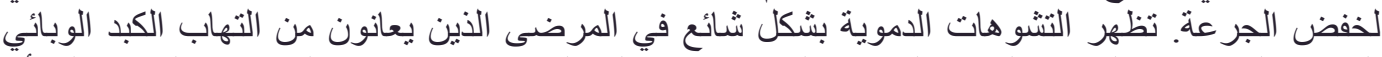

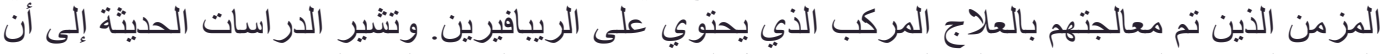

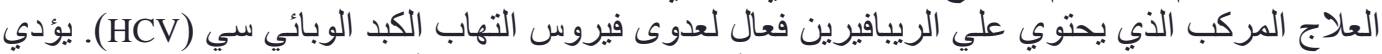

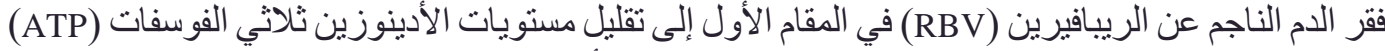

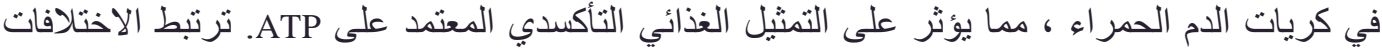

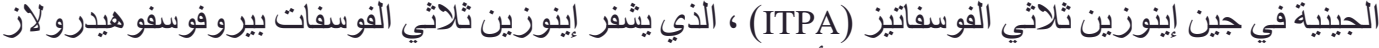

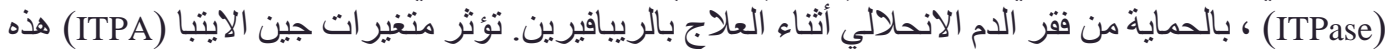

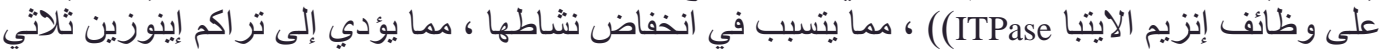

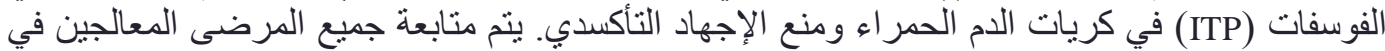

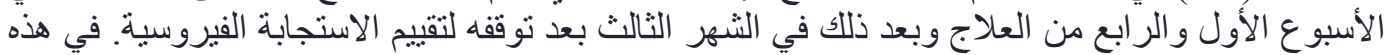

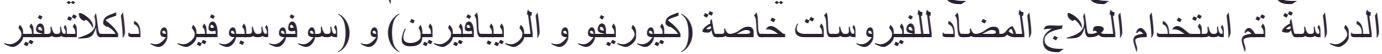

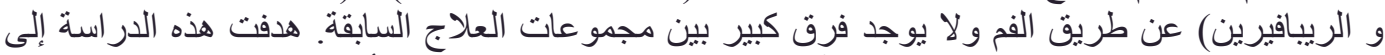

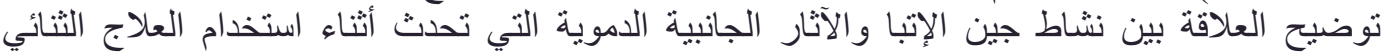
بالريبافيرين في المرضى الذين يعانون من تليف الكبد المرتبط بفيروس التئ التهاب التئ الكبد الوبائي (سي). 